\title{
Biology and Philosophy IV. The Presocratics.
}

\author{
Juan S. Gómez-Jeria
}

\begin{abstract}
Inner speech is examined and it is suggested that its appearance is limited to all or only some 'Homo sapiens-with Neanderthal DNA-with Denisovan DNA' mixed-breeds. The time relationships for Homo clausus, Homines aperti and animal-Homo are commented. Next, the appearance of the presocratic philosophers at Miletus and environs is analyzed trying to find a reasonable hypothesis explaining Thales' work. An attempt to resemble the processes that produce sudden changes in Ionian poetry with those that 'produced' Thales' works was unsuccessful. Archilochus' works look like the product of poetic influences from the geographical environment (Middle East, Egypt, Crete, Persia). In the case of Thales, it seems that he was the right man at the right time and place since he was able to put in written form what he had learned in Egypt and Babylonia. I suggest as a basal cause of Archilochus' and Thales' works a biological predisposition manifested as, for example, curiosity or a need to share aspects of their Homo clausus with others.
\end{abstract}

Index Terms - Presocratics, genetics, human evolution, Egypt, Babylonia, Thales, Phoenicia, Homo clausus, inner speech, Archilochus, Homines aperti.

Ne vaut-il pas mieux être Faust debout sur le Brocken, en butte à toutes les tempêtes qui souillent sur l'àme humaine du ciel et de la terre, que ce misérable Wagner, qui vit soixante ans heureux, mais bafoué, et ne s'aperçoit pas qu'il sert de jouet ridicule à la destinée? (Blaze de Buri about Goethe's Faust ${ }^{1}$ )

Love of money and nothing else will ruin Sparta (Oracle of Apollo at Delphi).

\section{INTRODUCTION}

'Lazy frogs' will always choose insignificant problems to study, or will work on petites variations of the same problem during their whole life. Therefore, as expected, they will never find deep or very general answers. These variations sur le même theme are very, very frequent in the scientific realm such as I have known during my lifetime. Several days ago I was doubtful about how I had written the previous papers in this series ${ }^{2-5}$, something I can summarize by saying 'when the choice lies between the marked path and the unmarked one, always follow the latter'. But recently I began to read the book Against the Grain. A deep history of the earliest states by James Scott ${ }^{-}$. It is a fascinating text. In the Preface I found an approach similar to the one I suggested and used: 'All these implications I draw from my reading of the evidence are meant to be provocations. They are intended to stimulate further reflection and research'. 'Where the evidence is thin and I stray into speculation, I try to signal that as well'

Juan S. Gómez-Jeria, Faculty of Sciences, University of Chile, Santiago, RM, Chile
Therefore, I will continue behaving that way. The central topic of this text is the so-called presocratic philosophers, a number of Greek philosophers who were active before and during the time of Socrates. Before I present the main part of this paper I feel it necessary to comment on social and inner speech.

\section{HUMAN INNER SPEECH: HOMO CLAUSUS AND HOMO APERTUS.}

There was a time when we were all animals like all others animals and nothing more. Our ancestors dealt only with things and maybe with changes of things. In the second paper of this series ${ }^{3}$ I suggested that during our evolution some Homo specimens crossed what I called the 'before/after' line that I dated about 40-50 kyr ago ${ }^{4}$. Immediately after crossing this boundary, the mixed-breed humans and human groups did not have creation accounts or any kind of cosmogony. This is the most primitive version of the Homo apertus ${ }^{\mathrm{T}}$. We know that words are only a small subset of the total activity of the $\operatorname{mind}^{8,9}$. Vocal communication is very ancient ${ }^{10,}, \underline{11}$. Our talking to ourselves (inner speech) is today a normal activity of almost all, if not all Homo sapiens but, and I think that this is obvious; there was a time when people living in Eurasia had only vocal communication and not a language. I suggest that only after crossing the 'before/after' boundary, after an unknown lapse of time, in a number of unknown individuals and in unknown place(s), the first 'internal words' began to appear (probably to name concrete objects ${ }^{12}$ ). These individuals were the first and most primitive members of the Homo clausus class ${ }^{\underline{T}}$ (I mean here that these first Homines clausi had a little world in themselves, but also that this inner world was not fully isolated from the 'world outside' because it was permanently or almost permanently interacting with it or feeding from it. Also I do not know yet if this definition of Homo clausus coincides with Elias' one ${ }^{7,} \underline{13}$ ). It is logical to say that 'internal words' should appear together with 'external words' (or maybe shortly thereafter). I think that this process was limited to all or to only some 'Homo sapiens-with Neanderthal DNA-with Denisovan DNA (at least)' mixed-breeds ${ }^{2}$. Note for future discussions that at least one viable offspring of a Neanderthal mother and a Denisovan father existed ${ }^{14}$.

Research on the origin and formation of languages in Eurasia can go back only about 15,000 years (a time where it is suggested that the whole Eurasian population seemed to speak a common language ${ }^{12}$ ). Only when an individual possesses a large enough number of 'internal words' and an unknown 'biological way' of connecting them in ordered 'strings of words' (please, do not think of actual internal strings of words!) having a meaning for him, at this moment the first 'internal questions' appear. What was the first 
question? We do not know. But, how marvelous the moment was when someone, somewhere in Eurasia, used his inner speech to ask himself 'WHY this?'! What was the structure of these first strings like? We do not know and probably we will never know. But these questions were formulated, I insist at this point, using the inner speech of his time. Do we have an explanation of the exact meaning of the material products of the Paleolithic? No, we don't. Do the red linear motif in La Pasiega, the hand stencil in Maltravieso (Extremadura) and the red-painted speleothems in Ardales (Andalucía) have symbolic meanings? We do not know. They are Neanderthal products dated to about 64.8 thousand years ago ${ }^{15}$. Think also of the Neanderthal building products found inside the Bruniquel Cave $\mathrm{C}^{\frac{16}{}}$. It is tempting to suggest that we acquired our present speech abilities because of the Homo sapiens-Neanderthal mixture. Even the Sulawesi paintings could have been made by people with a Homo sapiens-Neanderthal admixture (and with Denisovans too $)^{17}$.

The moment when more complex questions appeared such as 'where did we come from', 'why do we die' and what 'happens after one dies' is indeterminate. Normally one must follow with the assertion that at some stage creation stories and cosmogonies came into being. But this question does not seem to be the right one. Surely there were many different geographical places and times were our ancestors began to pose complex questions. And we do not know why the answers to the same questions were so different in some cases. But I think that all possibly have a common element: there was always a single first member of the group to provide an answer. And this individual was the same one who asked the question. There were no collective illuminations. The weather, the appearance of the night sky, earthquakes/tsunamis, meteors, shooting stars, droughts, volcanoes, the seasons, etc. surely played a role in some cases. And we know that many answers to the same questions are totally different and also that some groups of answers have a certain degree of similarity. But what we may hypothesize is that these minds were not separated into natural and supernatural realms: the fact that water falls from top to bottom in a waterfall and the fact that Ganymede, the most beautiful of mortals, was abducted by Zeus in the form of an eagle to serve as his cup-bearer on Mount Olympus are 'in the same box' with no internal contradictions. Note that I have suggested that the concepts of Homo clausus and Homo apertus may be endowed with biological foundations. This will be enlarged on another occasion, but I take this opportunity to affirm here that the existence of a Homo clausus is a necessary condition to produce intellectual knowledge, but not a sufficient one.

In each part of this paper where Homo clausus-I and data from the external world disagreed, I finally used the argument that seemed to me more tenable. What emerged was a really 'collaborative project'.

\section{THE PRESOCRATICS.}

Called by Aristotle physiologoi or physikoi, the presocratics seem to have been a new group of Homo sapiens sapiens different from the mythologoi or the theologoi. Kirk and Raven summarized our knowledge about presocratics with these words: "the actual fragments of the Presocratic thinkers are preserved as quotations in subsequent ancient authors, from Plato in the fourth century B.C. to Simplicius in the sixth century A.D., and even, in rare cases, to late Byzantine writers like John Tzetzes" $\underline{18}$. As I have some ideas to set forth here, I did a literature search to see if someone has written anything similar. On August 20, 2017, I opened the Internet Archive website (https://archive.org/). I searched for 'pre-socratic' and found 38 texts. I searched for 'presocratics' and found 18 texts. I searched for 'presocratic' and found 14 texts. After that, I visited the Library Genesis website (http://gen.lib.rus.ec/). A search for book titles containing 'pre-socratic' gave 12 results, for 'presocratics' 29 results and for 'presocratic' 77 results. A search in Google Scholar gave 12,100 results for 'pre-socratics', 21,500 results for 'pre-socratic', 12,900 results for 'presocratic' and 8,190 results for 'presocratics'. It is more or less obvious that it is impossible to read even one third of this material in a reasonable amount of time. Wow! How great language is! Starting from some fragments attributed to a relatively small number of apparently original thinkers, fragments that are not original but copied and recopied, some individuals have been able to send millions of trees to the paper mills to prove or disprove statements about them and comment on them again and again. It is enough for someone to say 'this phrase should have a comma here', 'this phrase should not have a comma here', 'this word must not have an accent mark here', 'this word must have an accent mark here', etc., to send another large group of trees to their death. Surely there must be a moment when, in spite of invoking one or more presocratics, some people are creating entirely new knowledge even without knowing that they are doing it. Anyway, with this enormous amount of printed paper we could build something looking like a mastaba as a tribute to these thinkers. I think that in areas where it is possible to write with impunity we shall end up creating something like 'The Library of Babel' 19. Perhaps the massive arrival of robotics and artificial intelligence will produce decent tools to dig into this enormous mass of intellectual production.

Now, if I may say so, I will use a new torch to cast a different light on the few facts we know about the Presocratics and try to present a global and full answer to the question 'why did it all start in Miletus and its environs?' It must be noted that this text is nothing more than a mere meditation on fragments of history, refusing to be just historiology $\underline{20}$.

\section{EVERYTHING STARTED IN MILETUS AND ENVIRONS.}

Van Melsen mentions in his book From Atomos to Atom ${ }^{21}$ that 'It is remarkable that the first Grecian philosophers about whom something is known generally come from the colonized regions of Asia Minor'. This show of astonishment is not new. For example, some time before and in his fictional work, M. l'abbé Barthélemy said: 'Jamais dans un si court espace, la nature n'a produit un si grand nombre de talens distingués et de génies sublimes. Hérodote naquit à Halicarnasse; Hippocrate à Cos; Thales à Milet; Pythagore à Samos; Parrhasius à Éphèse; Xénophane à Colophon; Anacréon à Téos; Anaxagore à Clazomènes ${ }^{, 22}$. 
First we need to mention some previous historical facts that are important for our comments. Greece was part of a world where, until the 12th century BCE, travel and exchanges were continuous. At this moment a catastrophe occurred (the "dark centuries"). Bottéro et al. summarized it as follows ${ }^{23}$ : 'Between the twelfth and the eleventh centuries those vast urban constructions, with their fortified palaces, disappeared. There was then a true regression, in every respect. By excavating tombs and studying the occupation of the territory, archeologists have been able to show that there was an enormous demographic decline. The countryside lost its population. At the same time their writing, which had played a role comparable to the one it played in the empires or the city-states of the Middle East, had been used to keep accounts of all the economic and religious activities that took place in the palaces. Writing had disappeared completely, except on Cyprus, but that was a particular case: it was a syllabic system derived from Linear B, and it created a type of Cypriot script that was still in use during the classical period. Everywhere else, writing disappeared completely, and it did not reappear, roughly speaking, until around the eighth century, perhaps at the end of the ninth $\underline{23}$. Between the 12th and the 9th centuries communication between the Greeks and Asia was basically interrupted ${ }^{24}$. In the 9th century, and maybe at the end of the 10th, the population grew, urban sites were developed and a vast effort of colonization began. The Greeks of continental Greece established colonies not only on the opposite coast of Asia (about 950 BCE) but also on the Black Sea and on the Mediterranean Sea (see the following map) ${ }^{25}$.

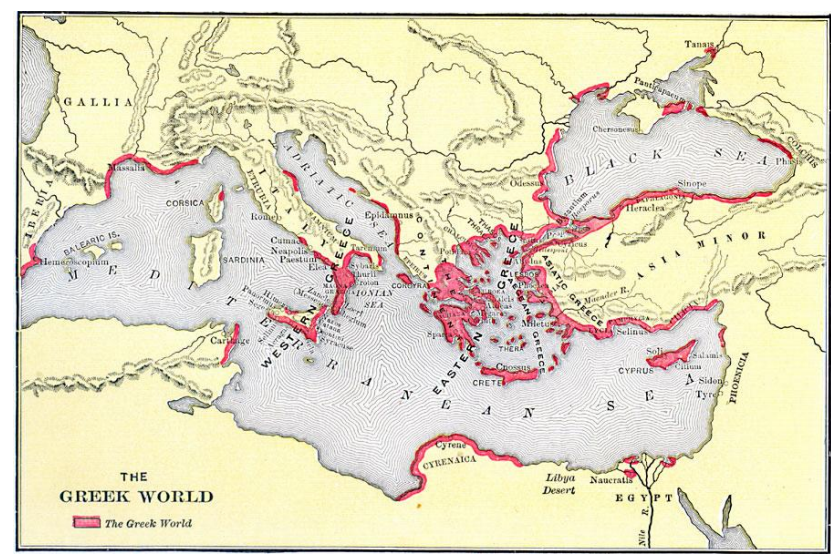

Vernant explains this colonization movement as " $a$ response to an acute demand for grain created by population pressure - a problem made all the greater by the fact that Hellenic agriculture tended now to favor the more profitable cultivation of vineyards and olive groves, whose products could be exported and traded. A search for land, for food, and for metal-such was the triple objective of Greek expansion across the Mediterranean" $\underline{26}, \underline{27}$.

Here we must mention for comparison that, around 1100 $\mathrm{BCE}$, the Phoenicians began creating colonies all across the Mediterranean, even on the Atlantic coasts of Europe and Africa. Examples of Phoenician colonies are Cadiz, Utica, Carthage, Malaga, Tangier, Rabat, Algiers, Bizerte, Tripoli, Leptis, Palermo, Solunto, Cagliari, Larnaka, etc. The following map shows the Greek and Phoenician colonies.

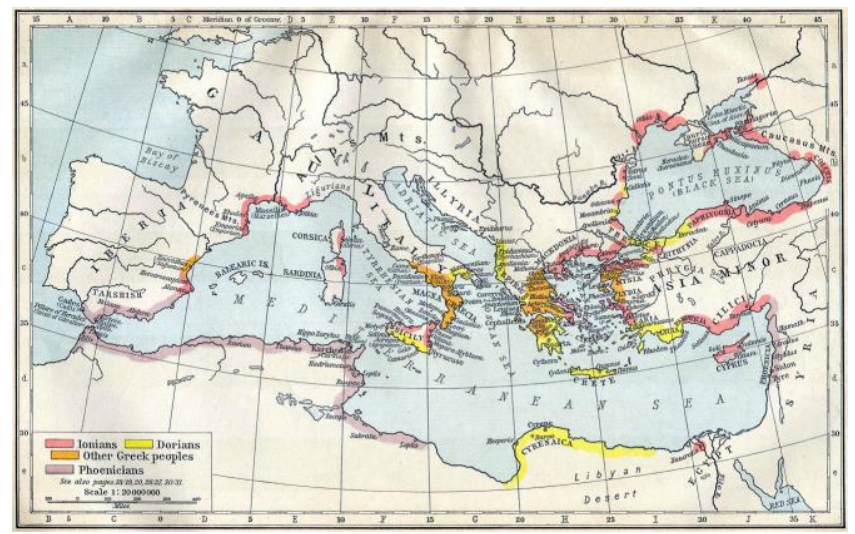

Literacy was gained, then lost in the convulsions of the 12th century BCE, then regained. When Homer and Hesiod were writing, the Greeks were just emerging from their dark age. Aside from the oral tradition, in which knowledge was transmitted in the form of sung poetry, a completely new form of writing appeared. The Greeks began to use a definite number of signs to denote vowels, writing becoming the translation of the spoken word. Given that writing was much easier to learn, with the passing of time it would penetrate all levels of society ${ }^{23}$. It was not until the late 8 th century BCE that their literature was first written down. The Iliad and Odyssey of Homer were put into written form probably around the end of the 8th century BCE. A bit more recent is Hesiod's Works and Days, which dates from approximately 650 BCE. "Hesiod is the first Greek poet to speak to the men of his own time in his own person" $\underline{28}$.

Let us chose the time of Thales of Miletus (624-546 BCE) as the starting point. The following map shows the political situation about $600 \mathrm{BCE}^{29}$.

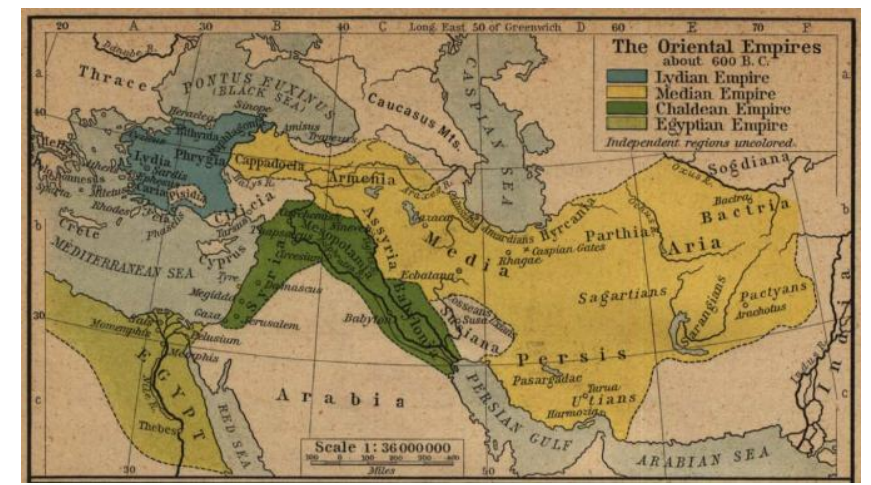

During the 6th century BCE, all of Anatolia was conquered by the Persian Achaemenid Empire. During that time there was an activity that is permanent: trade and exchange. But during the practice of these activities there is an exchange of tales, histories, fables, myths and all kinds of ideas. This is a two-way interchange.

According to Apollodorus of Athens, Thales was born in 624 BCE in the city of Miletus, located on western coast of Anatolia, close to the mouth of the River Maeander. He probably joined the family business early in his life. At those times, both Egypt and Babylonia were much more advanced than the Greeks, being leaders in building, mathematics and astronomy $\frac{30-37}{}$. Thales is alleged to have gone to Egypt to study geometry with the Egyptian priests $\underline{36}, \underline{38-41}$. On his return from Egypt, he introduced geometry into Greece (Proclus' statement). Later, he traveled to Babylonia to learn mathematics and astronomy from the Babylonians ${ }^{42}$. The 
prediction of the solar eclipse of May 28, 585 BCE (a suggested date), using the Saros Cycle (from the Chaldean astronomers) and/or data from Babylonian astronomy are indications of this fact. Thales seems also to have learned practical navigation from the Phoenicians. Thales discovered a practical method to determine the distance to a ship at sea. This specific example could perfectly be related to the shipping business of his family. While Thales was in Egypt, he was able to determine the height of a pyramid by measuring the length of its shadow when the length of his own shadow was equal to his height. This simple method also has practical applications.

Aetius stated about Thales that 'this man is supposed to be the originator of philosophy and from him the Ionian school gets its name.... Having practiced philosophy in Egypt he came to Miletus when he was older'. It is interesting to notice that the words 'is supposed' show the passage of time (about half a millennium from Thales's time) and the loss of certainty about his activities. But the story, lasting for about 2,600 years, stating that Thales was so determined to observe the stars that he failed to watch where he was walking and fell into a well is probably a remnant of his fame among the Greeks (Plato, Theaetetus, 174A). As far as we know, there were no large crowds in Asia Minor Ionian cities celebrating him, no long processions arriving at his home to hear the good news about the Universe.

Regarding the effect that non-Greek religious/ mythical/ etc. ideas had on Thales, Émile Bréhier wrote ${ }^{43}$ : 'il est impossible de ne pas sentir la parenté de pensée qu'il y a entre la thèse connue du premier philosophe grec, Thalès, que toutes choses sont faites d'eau, et le début du Poème de la Création, écrit bien des siècles auparavant en Mésopotamie: “Lorsqu'en haut le ciel n'était pas nommé, et qu'en bas la terre n'avait point de nom, de l'Apsou primordial, leur père, et de la tumultueuse Tiamat, leur mère à tous, les eaux se confondaient en un'"'. This is originally a Sumerian tradition. Kirk and Raven noticed that 'there are strong similarities between some of the Greek theogonical and cosmogonical stories and the theogonical myths of the great river-civilizations and their neighbours; these similarities help to explain some details of Greek accounts down to and including Thales $\stackrel{18}{ }$. Sumerians concluded that 'there was the primeval sea; the indications are that they looked upon the sea as a kind of first cause and prime mover, and they never asked themselves what preceded the sea in time and space, ${ }^{, 44}$. On his side, Horowitz's opinion is that 'it may be fair to suppose that water was a primordial element of the Sumerian universe, as it is in later Akkadian tradition, particularly that

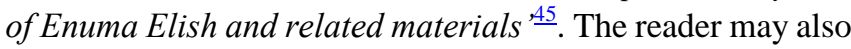
notice the many references to water, rivers, streams, dikes, canals, etc. in Sumerian poetry ${ }^{46}$. Also, a new and clever analysis of the geography of ancient Sumer showed the paramount importance of wetlands ${ }^{\underline{6}}$. Therefore, it is credible to think that it is highly possible that some Mesopotamian cultural elements made their way into Thales of Miletus's thought ${ }^{47}, \underline{48}$. With these considerations I should have to agree with the idea that 'water' was simply 'picked' from Sumerian or later traditions and that Thales' idea of the role of water was not a real breakthrough at that time. But I think that there are not enough elements to establish a full correspondence between the core intension of Sumerian 'water' and the core intension of Thales's 'water' ${ }^{49}$. Walter Burkert's book offers a good look at the influence of Near East cultures on archaic Greece $\underline{50}$.

Thales was part of an intellectual elite located in Miletus, together with Anaximander and Anaximenes (i.e., the so called Milesian school). From this city, this new way of thinking about things extended to Miletus's neighbours: Samos (Pythagoras), Colophon (Xenophanes) and Ephesus (Heraclitus, see the right side of the map below). When the Persian Empire's rule threatened Ionian cities Pythagoras and Xenophanes emigrated to Magna Graecia. One of the new cities, Elea, is known because of Parmenides and his follower Zeno.

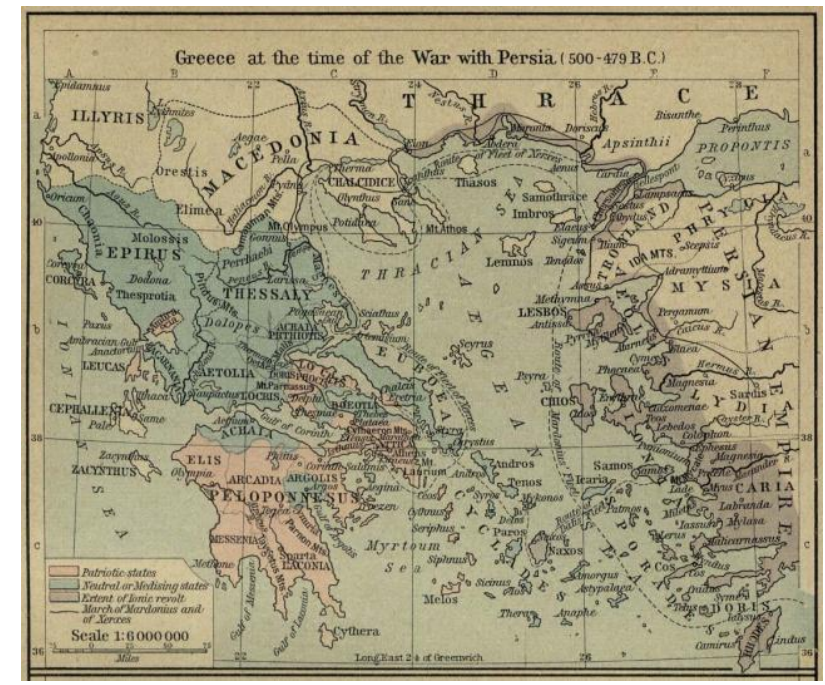

From a strict point of view the presocratics, considered as the first (Western) 'natural philosophers/scientists', do not have a historical connection with the European science represented by Copernicus, Cardano, Francis Bacon,

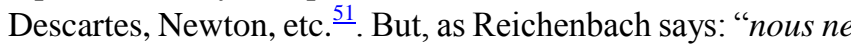
contestons certainement pas l'intérêt historique, l'utilité de suivre des analogies de vues à travers l'ancienne philosophie" (atomism for example).

My opinion is that, to understand what should be the supreme interesting characteristic of the presocratics, specially Thales, we shall first return to Jaeger's Paideia ${ }^{28}$ Jaeger states that "Their work [of the Ionians] in the development of the Greek spirit was to set the individual free - and it was so even in political life" initiative and wide vision are the chief characteristics of the new men created by these new conditions". The first brutal change is observed, for example, in the works of the lyric poet Archilochus (from the island of Paros) ${ }^{52-54}$ : "for the first time, poets spoke in their own persons, and expressed their own opinions and emotions, while the life of their community was relegated to the background of their thought" $\underline{28}$. No doubt that the external poetical work is produced by the poet's interior with its attention directed to the analysis of the inner world $\underline{55}$

We know that when Archilochus arrived in Sparta, they [the Spartans] ordered him to depart that very instant because they learned that he had written in his verses that it is better to throw away one's arms than to be killed $\underline{54}, \underline{56}$ :

'Shield that was mine, fair armour, now gladdens the heart 
of some Saian;

Sorry I left it behind tangled in brush in my path;

But for myself I escaped from the clutches of Death.

Let perdition take the old shield, for no worse surely I'll get the next time'.

We do not know what Archilochus wanted to mean exactly with these verses, and a fast trip through the related literature shows that almost all the possible meanings have been analyzed and defended or attacked. But regarding the moment of Archilochus' visit to Sparta, we have two possibilities: the Spartans were previously conscious of these verses or they became aware of them almost immediately after his arrival. Anyway the speed with which they expelled him from the city is an almost sure indication that these verses clashed frontally with the phrase with which Spartan mothers dismissed their children when they went to war: 'come back with your shield or on it'. As such, and remembering that Archilochus was cynical and critical of his contemporaries, these verses reject the values spread by the Homeric works which extolled honor and courage as values superior to life. Let us add that his diatribes were even said to have driven his first fiancée and her father to suicide. The importance of his works was such to the eyes of his contemporaries that a sanctuary to him (the Archilocheion) was established on his home island Paros about the third century BCE where his devotees offered him sacrifices. Let us note that no similar change of attitude is known to have happened in the literature of the Phoenician mother cities (Byblos, Sidon and Tyre). Was this mode of thought and composition followed by anyone? Yes, but only a few. And, as always, almost all the remaining people of Ionia continued behaving as they always did. Surely, the exact reason or reasons leading Archilochus to create his poetry are not known but we suggest that this new attitude could be a byproduct of the economic relationships with Crete, Egypt, Phoenicia, etc. No doubt that the sailors from other places knew poems and recited them sometimes. These excerpts from Ancient Egypt (new Kingdom) could be an example: 'To hear your voice is pomegranate wine to me: /I draw life from hearing it / Could I see you with every glance / It would be better for me /Than to eat or to drink". And 'I wish I were your mirror so that you always looked at me. I I wish I were your garment so that you would always wear me. I I wish I were the water that washes your body. I I wish I were the unguent, $O$ woman, that I could anoint you. / And the band around your breasts, and the beads around your neck'. We can see that the contents are quite different from Greek poetry. And it is very likely that the cultures established thousands of years ago had poems praising all aspects of life $\frac{48,57-60}{}$. This was a real and great novelty for the newcomers!

What we need to answer is why Thales was one of the first (if not the first) Homo sapiens sapiens who proposed materialistic explanations for natural phenomena, putting himself apart from myths and fables. There is no way to find an answer similar to that proposed for poetry. One example: Bottéro et al. simply stated the following (I changed the order of the phrasing for coherence): 'Thales played a political role in his city and quite probably made use of writing'. 'In the sixth century in the Greek colonies of Asia Minor, specifically in Miletus, a new type of writing appeared: this is seen first in Thales then in one of his pupils, Anaximenes, then in Anaximander. For Anaximander, this is an established fact. Thales's thoughts and the explanations he sets forth are written in prose. Thus there was a movement from oral poetry to written prose, and it had considerable consequences $\underline{\text {,23. }}$. First of all, there is not 'a movement from oral poetry to written prose' but only the appearance of written prose. And second, no explanation of ' $w$ hy Thales' is offered. In all the literature inspected I could not find as much as a suggestion.

What seems to have happened is possibly this: Thales had the opportunity of using written language to describe all the geometric knowledge he learned in Egypt (with his possible personal contributions) and his idea that the originating principle of nature was water. And, as this seems to have been a new activity in Ancient Greece, he was able to prove the following facts: that the angle in a semicircle is 90 degrees, that the pairs of vertical angles formed by two intersecting lines are equal, that a circle is bisected by a diameter, that if two triangles are such that two angles and a side of one are equal respectively to two angles and a side of the other, then the triangles are congruent and that the base angles of an isosceles triangle are equal.

He was the right man at the right time and place. Surely the manuscripts were an expensive product at that time and for this reason it would not be strange if Thales, Anaximenes and Anaximander belonged to the richer segment of the Milesian population. Geometry surely became a fascinating topic for some people from this very moment (with geometric algebra during Plato's times) and developed very fast $\frac{61-67}{}$.

Of course the immediate question is about the origins of this new mode of thinking. I ask this question because nothing similar is observed in the Phoenician cities or its colonies (as far as we know). And surely more than one Phoenician studied Egyptian and Babylonian science. I advocate a biological predisposition, defined as the increased chance of developing a pattern of behavior/thinking based on the genes we inherited from our parents and the parents of our parents, etc. This genetic load is different in each individual. To this biological substrate we must add the external environment that can allow or not a biological disposition to develop more or less through training and education. Obviously, you must have the chance to use this environment. An examination of many papers and books did not provide any suggestion regarding this hypothesis. Now the question is: biological predisposition for what could have some Ionian Greeks have had? Possible answers are curiosity (it has biological basis) and/or a need to show something to someone (poetry and Hesiod's works are earlier examples). But, and this is the most important thing, Thales of Miletus apparently had at least one disciple: Anaximander, who continued with this non-utilitarian way of looking at nature. Finally, Archilochus and Thales have something in common: in both of them, part of the 'content' of the Homo clausus (the internal feelings and the knowledge of abstract geometry) was transferred to the Homo apertus: poetry and Greek geometry are now a public matter and activities shared by all interested people, myself included. 


\section{REFERENCES.}

[1] Goethe, J. W. v.; Blaze de Bury (Ed. \& Trad.), H. Le Faust de Goethe: traduction complète, précédée d'un essai sur Goethe, accompagnée de notes et de commentaires et suivie d'une étude sur la mystique du poème. Charpentier: Paris, 1842.

[2] Gómez-Jeria, J. S. Biology and Philosophy. III. About Mongrels and How to Shoot down a Crab from a Tree. World Journal of Research and Review 2018, 7, 1-4.

[3] Gómez-Jeria, J. S. Biology and Philosophy. Part II. The Upper Paleolithic and the Holocene. World Journal of Research and Review 2017, 4, 42-47.

[4] Gómez-Jeria, J. S. Biology and Philosophy. Part I. The Paleolithic. World Journal of Research and Review 2017, 4, 21-28.

[5] Gómez-Jeria, J. S. Some remarks about the Graeae (Graiai). World Journal of Research and Review 2017, 4, 42-46.

[6] Scott, J. C. Against the Grain: A Deep History of the Earliest States. Yale University Press: New Haven \& London, 2018.

[7] Elias, N.; Jephcott (Trans.), E. The civilizing process. Blackwell Oxford: 1978; Vol. 1.

[8] Tart, C. T. Consciousness, altered states, and worlds of experience. Journal of Transpersonal Psychology 1986, 18, 159-170.

[9] Baars, B. J. The conscious access hypothesis: origins and recent evidence. Trends in Cognitive Sciences 2002, 6, 47-52.

[10] Gong, T.; Shuai, L.; Wu, Y. Rethinking foundations of language from a multidisciplinary perspective. Physics of Life Reviews 2018.

[11] Hauser, M. D.; Yang, C.; Berwick, R. C.; Tattersall, I.; Ryan, M. J.; Watumull, J.; Chomsky, N.; Lewontin, R. C. The mystery of language evolution. Frontiers in Psychology 2014, 5.

[12] Pagel, M.; Atkinson, Q. D.; S. Calude, A.; Meade, A. Ultraconserved words point to deep language ancestry across Eurasia. Proceedings of the National Academy of Sciences 2013, 110, 8471-8476.

[13] Penna, C. Homo Clausus, Homo Sacer, Homines Aperti: Challenges for Group Analysis in the 21st-Century. A Response to Haim Weinberg's 40th Foulkes Lecture. Group Analysis 2016, 49, 357-369.

[14] Slon, V.; Mafessoni, F.; Vernot, B.; de Filippo, C.; Grote, S.; Viola, B.; Hajdinjak, M.; Peyrégne, S.; Nagel, S.; Brown, S.; Douka, K.; Higham, T.; Kozlikin, M. B.; Shunkov, M. V.; Derevianko, A. P.; Kelso, J.; Meyer, M.; Prüfer, K.; Pääbo, S. The genome of the offspring of a Neanderthal mother and a Denisovan father. Nature 2018.

[15] Hoffmann, D. L.; Standish, C. D.; García-Diez, M.; Pettitt, P. B.; Milton, J. A.; Zilhão, J.; Alcolea-González, J. J.; Cantalejo-Duarte, P.; Collado, H.; de Balbín, R.; Lorblanchet, M.; Ramos-Muñoz, J.; Weniger, G.-C.; Pike, A. W. G. U-Th dating of carbonate crusts reveals Neandertal origin of Iberian cave art. Science 2018, 359, 912-915.

[16] Jaubert, J.; Verheyden, S.; Genty, D.; Soulier, M.; Cheng, H.; Blamart, D.; Burlet, C.; Camus, H.; Delaby, S.; Deldicque, D. Early Neanderthal constructions deep in Bruniquel Cave in southwestern France. Nature 2016, 534, 111.

[17] Aubert, M.; Brumm, A.; Ramli, M.; Sutikna, T.; Saptomo, E. W.; Hakim, B.; Morwood, M. v.; van den Bergh, G. D.; Kinsley, L.; Dosseto, A. Pleistocene cave art from Sulawesi, Indonesia. Nature 2014, 514, 223.

[18] Kirk, G. S.; Raven, J. E. The presocratic philosophers; a critical history with a selection of texts. University Press: Cambridge Eng., 1957; p xi, $486 \mathrm{p}$.

[19] Borges, J. L.; Desmazières, E.; Hurley, A.; Giral, A. The library of Babel. David R. Godine: Boston, 2000; p 36 p.

[20] Heidegger, M.; Rojcewicz (Trans.), R. Ponderings XII-XV: Black Notebooks, 1939-1941. Indiana University Press: Bloomington. IN, 2017.

[21] Melsen, A. G. M. v. From atomos to atom: the history of the concept atom. Dover Publications: Mineola, N.Y., 2004; p 240.

[22] Barthélemy, J.-J. Voyage du jeune Anacharsis en Grèce, dans le milieu du quatrième siècle avant l'ère vulgaire. Vol. IV. Debure l'aîne: Paris, 1788 .

[23] Bottéro, J.; Herrenschmidt, C.; Vernant, J.-P. Ancestor of the West: writing, reasoning, and religion in Mesopotamia, Elam, and Greece. University of Chicago Press: Chicago, 2000.

[24] Morris, I. Burial and ancient society: the rise of the Greek city-state. Cambridge University Press: Cambridge, 1987; p ix, 262 p., 1 p. of plates.

[25] Bogucki, P.; Crabtree, P. Ancient Europe 8000 BC-1000 AD: An Encyclopedia of The Barbarian World. Charles Scribner's Sons: New York, 2004.

[26] Vernant, J. P. The origins of Greek thought. Cornell University Press: Ithaca, N.Y., 1982; p 144 p.

[27] Roebuck, C. Ionian trade and colonization. Archaeological Institute of America: New York, 1959.
[28] Werner, J.; Highet (Trans.), G. Paideia: The ideals of Greek culture. Oxford University Press: New York, 1945.

[29] Shepherd, W. R. Historical Atlas. Henry Holt and Company: New York, 1911.

[30] Neugebauer, O. A history of ancient mathematical astronomy. Springer-Verlag: Heidelberg, 1975

[31] Evans, J. The history and practice of ancient astronomy. Oxford University Press: Oxford, 1998.

[32] Horowitz, W. Mesopotamian Cosmogony and Cosmology. In Handbook of Archaeoastronomy and Ethnoastronomy, Ruggles, C. L. N., Ed. Springer New York: New York, NY, 2015; pp 1823-1827.

[33] McLeod, A. Astronomy in the Ancient World. Springer: Switzerland, 2016; p 1-8.

[34] Damerow, P.; Hoyrup, J. Changing Views on Ancient Near Eastern Mathematics. In Dietrich Reimer Verlag: Berlin, 2001.

[35] Hodgkin, L. A history of mathematics: from Mesopotamia to modernity. Oxford University Press: Oxford, 2005.

[36] Katz, V. J. The Mathematics of Egypt, Mesopotamia, China, India, and Islam: A Sourcebook. Princeton University Press: Princeton, 2007.

[37] Robson, E. Mathematics in ancient Iraq: A social history. Princeton U. Press: Princeton, 2008

[38] Clagett, M. Ancient Egyptian Science. A Source Book. Volume III. Ancient Egyptian Mathematics. American Philosophical Society

[39] Philadelphia, 1999.

[40] Rossi, C. Architecture and mathematics in ancient Egypt. Cambridge University Press: Cambridge, 2004.

[41] Reimer, D. Count like an Egyptian. Princeton University Press: Princeton, 2014.

[42] Imhausen, A. Mathematics in ancient Egypt: a contextual history. Princeton University Press: Oxford, 2016.

[43] Graham, D. W. The texts of early Greek philosophy: the complete fragments and selected testimonies of the major Presocratics. Cambridge University Press: Cambridge, 2010; Vol. 1.

[44] Brehier, E. Histoire de la philosophie. Tome premier, L'Antiquité et le Moyen Âge. Librairie Félix Alcan: Paris, 1926.

[45] Kramer, S. N. The Sumerians: their history, culture, and character. University of Chicago Press: Chicago, 1963; p xiv, 355 p.

[46] Horowitz, W. Mesopotamian Cosmogony and Cosmology. Handbook of Archaeoastronomy and Ethnoastronomy 2015, 1823-1827.

[47] Jacobsen, T. The Harps that once...: Sumerian poetry in translation. Yale University Press: New Haven, 1997; p xv, 498 p.

[48] Shepherd, W. R.; C.S. Hammond \& Company. Historical atlas. In Henry Holt and Co.: New York, 1911; p v.

[49] Pritchard, J. B. Ancient Near Eastern texts relating to the Old Testament. Third Edition with Supplement. 2d ed.; Princeton University Press: Princeton,, 1992.

[50] Bunge, M. Scientific research. I. The search for a system. Springer-Verlag: Berlin, 1967.

[51] Burkert, W. The orientalizing revolution: Near Eastern influence on Greek culture in the early archaic age. Harvard University Press: Cambridge, Mass., 1992; p 225 p.

[52] Reichenbach, H.; Vouillemin (Trad.), E. La Philosophie Scientifique, Vues Nouvelles Sur Ses Buts Et Ses Méthodes. Hermann et Cie.: Paris, 1932.

[53] Will, F. Archilochus and His Senses. The Classical Journal 1962, 57 , 289-296.

[54] Seidensticker, B. Archilochus and Odysseus. Greek, Roman, and Byzantine Studies 1978, 19, 5-22.

[55] Anderson, C. A. Archilochus, his lost shield, and the heroic ideal. Phoenix 2008, 62, 255-260.

[56] Russo, J. The inner man in Archilochus and the Odyssey. Greek, Roman, and Byzantine Studies 1974, 15, 139-152.

[57] Plutarch; Babbitt (Trans.), F. C. Moralia. Vol. III. 172A-263C. William Heinemann Ltd.: London, 1961.

[58] Foster, B. R. Before the muses: an anthology of akkadian literature. CDL Press: Bethesda, 1996; Vol. 2.

[59] Smith, M. S.; Parker, S. B. Ugaritic narrative poetry. Society of Biblical Literature: Atlanta, 1997.

[60] Faulkner, R. O. The literature of ancient Egypt: an anthology of stories, instructions, stelae, autobiographies, and poetry. Yale University Press: London, 2003.

[61] Black, J. A. The literature of ancient Sumer. Oxford University Press: Oxford ; New York, 2004; p lxiii, 372 p.

[62] Christianidis, J. Classics in the history of Greek mathematics. Springer Science \& Business Media: Dordrecht, 2004; Vol. 240.

[63] Gow, J. A short history of Greek mathematics. Cambridge University Press: Cambridge, 2010.

[64] Klein, J. Greek mathematical thought and the origin of algebra. Dover Publications: New York, 1992. 
World Journal of Research and Review (WJRR)

ISSN: 2455-3956, Volume 7, Issue 4, October 2018 Pages 44-50

[65] Netz, R. The shaping of deduction in Greek mathematics: A study in cognitive history. Cambridge University Press: Cambridge, 2003; Vol. 51.

[66] Sialaros, M. Revolutions and Continuity in Greek Mathematics. Walter de Gruyter: Berlin, 2018.

[67] Szabó, Á. The beginnings of Greek mathematics. D. Reidel: Dordrecht, 1978.

[68] Knorr, W. R. The evolution of the Euclidean Elements: A study of the theory of incommensurable magnitudes and its significance for early Greek geometry. D. Reidel: Dordrecht, 1975.

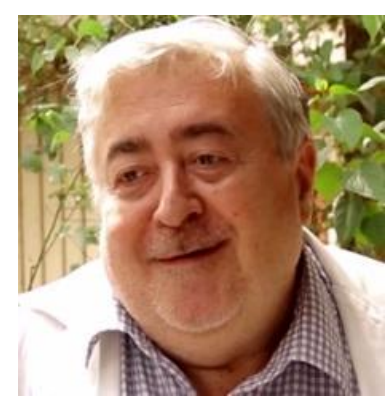

Juan Sebastián Gómez-Jeria. Graduate in Chemistry and Chemist at the University of Chile, $\mathrm{PhD}$ in Molecular Physical Chemistry (UNAB). Research in Quantitative Structure-Activity relationships, electronic structure of nanostructures and philosophy of science. Lecturer in Quantum Chemistry and Quantum Pharmacology and History and Philosophy of Science. He has published three books and more than 170 papers. He is preparing the book Biology and Philosophy. 